\title{
Status and distribution of endemic and threatened birds of the Eastern Himalaya in Sikkim, India
}

\author{
Bhoj Kumar Acharya ${ }^{1} \&$ Lalitha Vijayan ${ }^{2}$ \\ 1,2 Sàlim Ali Centre for Ornithology and Natural History, Anaikatty, Coimbatore, Tamil Nadu 641108, India \\ Present address: ${ }^{1}$ Department of Zoology, Sikkim Government College, Tadong, Gangtok, Sikkim 737102, India \\ Email: ${ }^{1}$ acharya2skm@gmail.com, ${ }^{2}$ vijayanlalitha @yahoo.com
}

Date of publication (online): 26 February 2010 Date of publication (print): 26 February 2010 ISSN 0974-7907 (online) | 0974-7893 (print)

Editor: Geeta Padate

\section{Manuscript details:}

Ms \# 02257

Received 09 July 2009

Final received 26 November 2009

Finally accepted 15 December 2009

Citation: Acharya, B.K. \& L. Vijayan (2010). Status and distribution of endemic and threatened birds of the Eastern Himalaya in Sikkim, India. Journal of Threatened Taxa 2(2): 685-689.

Copyright: (๑) Bhoj Kumar Acharya \& Lalitha Vijayan 2010. Creative Commons Attribution 3.0 Unported License. JoTT allows unrestricted use of this article in any medium for non-profit purposes, reproduction and distribution by providing adequate credit to the authors and the source of publication.

Author details: BhoJ Kumar Acharya completed PhD from Sálim Ali Centre for Ornithology and Natural History, Coimbatore, India in 2008. Currently he is an Assistant Professor in Sikkim. His research focuses pattern in diversity and distribution of birds, butterflies and plants in the Himalayan elevation gradient. LaLITHA VIJAYAN is Senior Principal Scientist at SACON, Coimbatore. She has expertise on avian biology and conservation ecology with experience of working on birds and their habitats for the last three decades. Her recent research focus is on community ecology of birds and conservation of threatened birds in India.

Author Contribution: BKA undertook field study, analyzed data and wrote the manuscript. LV supervised BKA during filed study and provided necessary suggestions during manuscript preparation.

Acknowledgements: This paper forms a part of the ecological study on mammals, birds, herpetofauna and butterflies in Sikkim, funded by the Ministry of Environment and Forests, Government of India through CISMHE, University of Delhi. We are thankful to the Government of Sikkim for necessary permissions, and founder Director, SACON for providing facilities to work We thank Ajith Kumar, S. Bhupathy, Basundhara Ranjini and Nikhil for their cooperation and suggestions, and field assistants for their support during the field work.
Abstract: Due to their restricted distribution range and dwindling population endemic and threatened species need considerable attention from ecologists. Sikkim is a part of the Eastern Himalayas Endemic Bird Area that represents high concentrations of globally threatened species. This study collected information on endemic and threatened birds of Sikkim using point count method. The number of species and their density at five elevation zones were calculated. Out of 10 species endemic to Sikkim, five were recorded during the present study. These species were restricted to one to three habitats but densities varied among the habitats. Similarly, out of 17 threatened and 10 near-threatened species of birds that occur in Sikkim, we could observe only three species. The results show that these birds are rare or their occurrence is doubtful in recent years. The principal threat to birds in the state appears to be loss of breeding habitat. Species-specific studies focusing on population status, habitat requirements and assessment of threats are necessary for the execution of conservation measures.

Key words: Birds, conservation, endemic, Eastern Himalaya, Sikkim, threatened.

\section{INTRODUCTION}

Restricted range and threatened bird species need considerable attention from ecologists and conservationists compared to wide ranging and common species. These species are more sensitive to disturbance and invite immediate conservation concern (BirdLife International 2001; Lei et al. 2003, 2007; Wijesinghe \& Brooke 2005; Pandit et al. 2007). Information on status and distribution of threatened and endemic birds, therefore, aids in prediction of disturbance level and execution of conservation measures at all potential sites of their occurrence (Stattersfield et al. 1998; Riley 2002; Robin \& Sukumar 2002).

The Eastern Himalaya is represented by diverse habitats and has high variations in altitude and climate. This habitat supports a high diversity of birds and is one of the most diverse regions in the Orient (Crosby 1996). The Eastern Himalayan Mountain range is identified as an endemic bird area (BirdLife International 2001), which supports 22 restricted-range bird species of which 19 are endemic to the Eastern Himalayas (Stattersfield et al. 1998; Jathar \& Rahmani 2006; IUCN 2009). The region also represents one of the largest concentrations of globally threatened birds in Asia. The principal threat to the avifauna of Himalaya is the loss of habitat; particularly tropical lowland, sub-tropical and temperate forests (Crosby 1996).

Sikkim lies within the Eastern Himalaya Endemic Bird Area (Islam \& Rahmani 2004). Out of the 19 endemic bird species of the Eastern Himalaya, 10 are reported to occur in Sikkim. It also represents a relatively higher number of threatened bird species. Out of the 78 threatened birds of the Indian Sub-continent, 17 (1 Endangered, 3 Critically Endangered and 13 Vulnerable) occur in Sikkim (IUCN 2009). Similarly, 10 Near Threatened species of birds are also reported from Sikkim.

Baseline information on distribution of a few endemic and threatened birds of the Eastern Himalaya is available (Stattersfield et al. 1998; Mauro \& Vercruysse 2000; Ali \& Ripley 2001; BirdLife International 2001; Acharya \& Vijayan 2007). No study has been conducted to asses the status of endemic and threatened birds in Sikkim. This paper discusses the status and distribution of the Eastern Himalayan endemic, threatened and near-threatened bird species in Sikkim. Conservation measures are also highlighted in brief.

\section{Materials and Methods}

Study area: Sikkim $\left(27^{\circ} 03^{\prime}-28^{\circ} 07^{\prime} \mathrm{N} \& 88^{\circ} 03^{\prime}-88^{\circ} 57^{\prime} \mathrm{E}\right)$, a small state of India, is situated at the western extremities of the Eastern Himalaya (Image 1). Within the $7096 \mathrm{~km}^{2}$ area it has a varied climate, topography, vegetation and altitudinal ranges. As rainfall varies from $2000-5000 \mathrm{~mm}$, Sikkim is considered the wettest region in the 

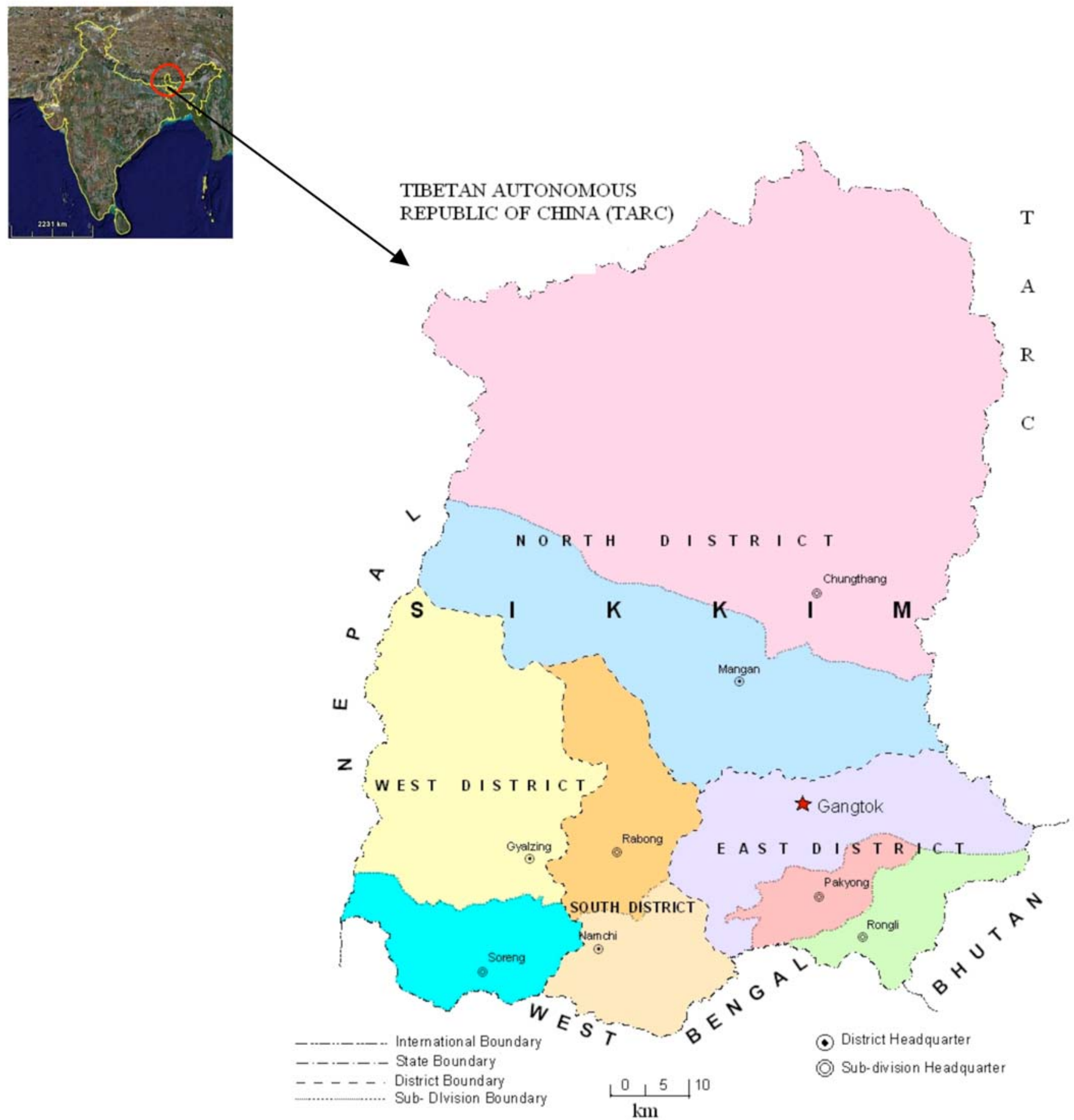

Image 1. Map of Sikkim showing its prominent locations

entire Himalayan belt (Ali 1962; Mani 1974) with a relative humidity of $70-80 \%$ throughout the year. The climate varies from hot tropical at the lower elevations to cool temperate at the middle and arctic cold at the higher elevations. The altitude ranges from $300 \mathrm{~m}$ to more than $8000 \mathrm{~m}$. Vegetation, which is chiefly determined by elevation and various physical and ecological factors, changes from tropical to sub-tropical, temperate broadleaved, mixed coniferous, sub-alpine and alpine. The alpine zone represents the typical trans-Himalayas.

\section{Methods}

Point count method (Bibby et al. 2000) was used along the predetermined transects for sampling birds. On encountering a bird, details such as species, number of individuals and the distance from the observer when first sighted were noted. Depending upon the vegetation and elevation of the study area, sampling sites were divided into five zones. These are Zone I (<900m) - tropical semi-deciduous forests; Zone II (900$1800 \mathrm{~m})$ - tropical moist and broad-leaved forests; Zone III (1800-2800m) - temperate broad-leaved forests; Zone IV (2800$3800 \mathrm{~m})$ - temperate coniferous and broad-leaved forests; and 
Table 1. Endemic birds of Sikkim. Numbers indicate density (numbers/ha) of birds observed during the study in different elevation zones $\{$ I $(<900 \mathrm{~m})$, II $(900-1800 \mathrm{~m})$, III $(1800-2800 \mathrm{~m})$, IV $(2800-3800 \mathrm{~m})$ and V (3800-4500m and above)\} representing different vegetation types) in Sikkim.

\begin{tabular}{|c|c|c|c|c|c|c|}
\hline Species & $\mathbf{I}$ & II & III & IV & V & $\mathbf{A Z}$ \\
\hline Broad-billed Warbler, Tickellia hodgsoni & - & 0.37 & 1.84 & 5.95 & - & II, III \\
\hline Chestnut-breasted Partridge, Arborophila mandellii & - & - & - & - & - & I, II, III \\
\hline Giant Babax, Babax waddelli & - & - & - & - & - & * \\
\hline Hoary-throated Barwing, Actinodura nipalensis & - & 0.40 & 5.36 & - & - & II, III, IV \\
\hline Rufous-throated Wrenbabbler, Spelaeornis caudatus & - & - & - & - & - & IV \\
\hline Rusty-bellied Shortwing, Brachypteryx hyperythra & - & - & 1.33 & 3.22 & - & III, IV \\
\hline Ward's Trogon, Harpactes wardii & - & - & - & - & - & * \\
\hline Wedge-billed Wrenbabbler, Sphenocichla humei & - & - & - & - & - & V \\
\hline White-naped Yuhina, Yuhina bakeri & 2.38 & 7.80 & 1.03 & - & - & I, II, III \\
\hline Yellow-vented Warbler, Phylloscopus cantator & 1.61 & 7.44 & - & - & - & I, II, III \\
\hline
\end{tabular}

AZ - reported altitude zone for species; - - denotes species not observed during the present study;

* - distribution of species not known.

Table 2. Threatened birds of Sikkim (IUCN 2009). Numbers indicate density (numbers/ha) of birds observed during the study in different elevation zones $\{$ I $(<900 \mathrm{~m})$, II $(900-1800 \mathrm{~m})$, III $(1800-2800 \mathrm{~m})$, IV $(2800-3800 \mathrm{~m})$ and V (3800-4500m and above)\} in Sikkim.

\begin{tabular}{|c|c|c|c|c|c|c|c|}
\hline Species & I & II & III & IV & V & $\mathbf{A Z}$ & Status \\
\hline Baer's Pochard, Aytha baeri & - & - & - & - & - & III & EN \\
\hline Beautiful Nuthatch, Sitta formosa & - & - & - & - & - & I, II, III & VU \\
\hline Black-necked Crane, Grus nigricolis & - & - & - & - & - & V & VU \\
\hline Black-breasted Parrotbill, Paradoxornis flavirostris & - & - & - & - & - & I, II, III & VU \\
\hline Blyth's Kingfisher, Alcedo hercules & - & - & - & - & - & 1 & NT \\
\hline Blyth's Tragopan, Tragopan blythii & - & - & - & - & - & * & VU \\
\hline Chestnut-breasted Partridge, Arborophila mandellii & - & - & - & - & - & I, II, III & VU \\
\hline Cinereous Vulture, Aegypius monachus & & & & & & & NT \\
\hline Firethroat, Luscinia pectardens & - & 4.78 & - & - & - & II, III & NT \\
\hline Giant Babax, Babax waddelli & - & - & - & - & - & V & NT \\
\hline Great Hornbill, Buceros bicornis & - & - & - & - & - & $\mathrm{I}, \mathrm{II}$ & NT \\
\hline Greater Spotted Eagle, Aquila clanga & - & - & - & - & - & * & VU \\
\hline Grey-crowned Prinia, Prinia cinereocapilla & - & - & - & - & - & $\mathrm{I}, \mathrm{II}$ & VU \\
\hline Hodgson's Bushchat, Saxicola insignis & - & - & - & - & - & * & VU \\
\hline Lesser Kestrel, Falco naumanni & - & - & - & - & - & * & VU \\
\hline Long-billed Vulture, Gyps indicus & - & - & - & - & - & * & CR \\
\hline Palla's Fish Eagle, Haliaeetus leucoryphus & - & - & - & - & - & I, II, III, IV & VU \\
\hline Red-headed Vulture, Sarcogyps calvus & - & - & - & - & - & * & CR \\
\hline Rufous-necked Hornbill, Aceros nipalensis & - & - & - & - & - & * & VU \\
\hline Rufous-throated Wrenbabbler, Spelaeornis caudatus & - & - & - & - & - & IV & NT \\
\hline Rusty-bellied Shortwing, Brachypteryx hyperythra & - & - & 1.33 & 3.22 & - & III, IV & NT \\
\hline Satyr Tragopan, Tragopan satyra & - & - & 0.42 & - & - & III, IV, V & NT \\
\hline Slender-billed Babbler, Turdoides longirostris & - & - & - & - & - & * & VU \\
\hline Ward's Trogon, Harpactes wardii & - & - & - & - & - & * & NT \\
\hline White-rumped Vulture, Gyps bengalensis & - & - & - & - & - & * & CR \\
\hline Wood Snipe, Gallinago nemoricola & - & - & - & - & - & * & VU \\
\hline Yellow-rumped Honeyguide, Indicator xanthonotus & - & - & - & - & - & III & NT \\
\hline
\end{tabular}

AZ - reported altitude zone for species; - - denotes species not observed during the present study; * - distribution of species not known; EN - Endangered; CR - Critically Endangered; VU - Vulnerable; NT - Near Threatened.

Zone V (3800-4500m and above) - sub-alpine and alpine vegetation. Permanent points were established in each transect. Points were replicated 9-12 times covering different seasons during 2003 to 2006 . In addition, surveys were also conducted covering various parts of the state.

The number of species and density of species in each zone were estimated. Density was calculated based on Reynolds et al. (1980); $D=n^{*} 10000 / \pi r^{2} C$, where $D=$ bird density (numbers/ha), $\mathrm{n}=$ total number of birds observed in all counts within the specific radius, $r=$ specific radius $(m), C=$ total number of counts conducted and $\pi=3.14$. The information on altitudinal distribution was obtained from literature (Ali 1962; Stattersfield et al. 1998; Ali \& Ripley 2001; BirdLife International 2001; Islam \& Rahmani 2004) as well as field observations.

\section{RESULTS}

A total of 573 species of birds occur in Sikkim (Acharya \& Vijayan unpublished data) of which ten are endemic. Out of these endemic species, we observed only five species during this study (Table 1). A maximum of four endemic species were recorded in zone II and III followed by two species each in zone I and IV. While no endemic species was found in the alpine zone of Sikkim.

Among the five species recorded by us, Rusty-bellied Shortwing Brachypteryx hyperythra was rare with a density of 1.33/ha and 3.22/ha in zone III and IV respectively. The other four species (Broad-billed Warbler Tickellia hodgsoni, Hoarythroated Barwing Actinodura nipalensis, Yellow-vented Warbler Phylloscopus cantator and White-naped Yuhina 
Yuhina bakeri) were locally abundant and observed in two or three elevation zones. The density of Broad-billed Warbler was highest in zone IV, Hoary-throated Barwing in zone III and White-naped Yuhina and Yellow-vented Warbler in zone II (Table 1).

Among the threatened and near-threatened species that occur in Sikkim, only three species (Rusty-bellied Shortwing Brachypteryx hyperythra, Firethroat Luscinia pectardens and Satyr Tragopan Tragopan satyra) were observed during the study (Table 2). Satyr Tragopan was recorded in zone III, Firethroat in zone II, whereas Rusty-bellied Shortwing was detected in zones III and IV. It is to be noted that densities of these species were very low ( $<5$ birds/ha). Elevation range and habitat of 10 threatened and two near-threatened species is still unknown (Table 2).

\section{Discussion and Conclusions}

Five endemic species, namely Chestnut-breasted Partridge Arborophila mandellii, Wedge-billed Wrenbabbler Sphenocichla humei, Rufous-throated Wrenbabbler Spelaeornis caudatus, Ward's Trogon Harpactes wardii and Giant Babax Babax waddelli were not observed during the course of this study. Among these species, Chestnut-breasted Partridge was reported to occur in habitats similar to zones I, II and III, Rufous-throated Wrenbabbler to zone IV and Wedgebilled Wrenbabbler to zone V (Ali 1962; Ali \& Ripley 2001; Islam \& Rahmani 2004) but the distribution of the rest two is not known.

Similarly, out of the 17 threatened and ten near-threatened birds of Sikkim (IUCN 2009), only three near-threatened species (Rusty-bellied Shortwing, Firethroat and Satyr Tragopan) were observed in Sikkim during this study. Species such as Palla's Fish Eagle Haliaeetus leucoryphus, Blackbreasted Parrotbill Paradoxornis flavirostris, and Beautiful Nuthatch Sitta formosa are reported to have a wider distribution range but the other species such as White-rumped Vulture Gyps bengalensis, Long-billed Vulture Gyps indicus, Redheaded Vulture Sarcogyps calvus, Baer's Pochard, Aytha baeri, Greater Spotted Eagle Aquila clanga, Lesser Kestrel Falco naumanni, Blyth's Tragopan Tragopan blythii, Blacknecked Crane Grus nigricolis, Slender-billed Babbler Turdoides longirostris, Rufous-necked Hornbill, Aceros nipalensis and Wood Snipe Gallinago nemoricola have merely presence-absence records in Sikkim (Ali 1962; GanguliLachungpa 1998; Ali \& Ripley 2001; Islam \& Rahmani 2004).

The result indicates that the population of these birds in Sikkim is very low. Habitat loss and fragmentation is considered the major factor for decline in population of threatened and endemic birds in the Himalaya and elsewhere (Crosby 1996; Mauro \& Vercruysse 2000; BirdLife International 2001; Chettri et al. 2001, 2005; Riley 2002; Robin \& Sukumar 2002; Pandit et al. 2007). It is reported that endemic birds are unable to utilize non-forest habitats resulting from deforestation and conversion of land to other uses (Lei et al. 2003; Wijesinghe \& Brooke 2005; Vijayan \& Gokula 2006). Fragmentation and loss of habitat of the restricted range species threatens their very survival (Lei et al. 2003). The study by Pandit et al. (2007) predicts that by the end of this century, a quarter of the endemic species of the Himalaya will be extinct due to habitat loss. Extinction of endemic species is primarily driven by the loss of potential breeding habitat (Mauro \& Vercruysse 2000; BirdLife International 2001).

Maximum species of endemics and threatened birds in
Sikkim are found in tropical broadleaved forests (zone II) and temperate broadleaved forests (zone III). The diversity of birds is also high in these zones (Acharya 2008). Tropical and temperate broadleaved forests are breeding ground for most of these species but human population pressures and various ongoing developmental projects have posed serious threats to these habitats. The forests in zone II is outside the purview of current protected area network (Acharya et al. 2008). Hence, conservation through community participation would be effective for conservation of birds in these habitats.

This study was undertaken as a part of the bird community study in Sikkim which was more focused to understand the distribution pattern of birds along elevation gradient (Acharya 2008). Hence, some species might have been missed or densities underestimated though special attention was given to endemics and threatened birds. Long-term specific study on these species provides better understanding of population status, distribution and threat. Hence, detailed study on the ecological aspects and habitat requirements is necessary for the execution of species-specific conservation measures.

\section{REFERENCES}

Acharya, B.K. (2008). Bird communities and their distribution pattern along the elevation gradient of Teesta Valley, Sikkim. Ph.D. Thesis. Bharathiar University, Coimbatore, India.

Acharya, B.K. \& L. Vijayan (2007). Range extension of Rusty-bellied Shortwing Brachypteryx hyperythra in Sikkim, India. Birding Asia 7: $50-51$.

Acharya, B.K., L. Vijayan \& B. Chettri (2008). Conservation priorities based on altitudinal distribution of species in Sikkim, Eastern Himalaya. Paper presented at International Congress of Society for Conservation Biology, Convention Center, Chattanooga, TN, USA, 13-17 July 2008.

Ali, S. (1962). The Birds of Sikkim. Oxford University Press, New Delhi, 414pp.

Ali, S. \& S.D. Ripley (2001). Handbook of the Birds of India and Pakistan, Vol. 1 to 10. Oxford University Press, New Delhi.

Bibby, C.J., N.D. Burgess, D.A. Hill \& S.H. Mustoe (2000). Bird census techniques. Academic Press, London, 302pp.

BirdLife International (2001). Threatened birds of Asia: the BirdLife International Red data book. BirdLife International,Cambridge, U.K., 3,038pp.

Chettri, N., E. Sharma \& D.C. Deb (2001). Bird community structure along a trekking corridor of Sikkim Himalaya: a conservation perspective. Biological Conservation 102: 1-16.

Chettri, N., R. Jackson \& E. Sharma (2005). Birds of Khecheopalri and Yuksom-Dzongri trekking corridor west Sikkim. Journal of Hill Research 18: 16-25.

Crosby, M. (1996). Threatened birds in the eastern Himalayas. Oriental Bird Club Bulletin 23: 21-23.

Ganguli-Lachungpa, U. (1998). Attempted breeding of the Blacknecked Crane Grus nigricollis przevalski in north Sikkim. Journal of Bombay Natural History Society 95: 341.

Islam, Z.M. \& A.R. Rahmani (2004). Important Bird Areas in India: priority sites for conservation. Bombay Natural History Society, Mumbai. pp. 898-931.

IUCN (2009). IUCN Red List of Threatened Species. <http:// www.iucnredlist.org.>. On-line version 2009.1 dated 14 June 2009.

Jathar, G.A. \& A.R. Rahmani (2006). Endemic birds of India. Buceros 11: 5-53.

Lei, F.M., Y.H. Qu, J.L. Lu, Y.Liu \& Z.H. Yin (2003). Conservation on diversity and distribution patterns of endemic birds in China. Biodiversity and Conservation 12: 239-254.

Lei, F.M., G.A. Wei, H.F. Zhao, Z.H. Yin \& J.L. Lu (2007). China subregional avian endemism and biodiversity conservation. Biodiversity and Conservation 16: 1119-1130.

Mani, M.S. (1974). Ecology and Biogeography in India. Dr. W. Junk Publishers, The Hague, 773pp. 
Mauro, I. \& E. Vercruysse (2000). Rusty-bellied Shortwing Brachypteryx hyperythra at Lava, Darjeeling, India in April and June 1996. Forktail 16: 176-178.

Pandit, M.K., N.S. Sodhi, L.P. Koh, A. Bhaskar \& B.W. Brook (2007). Unreported yet massive deforestation driving loss of endemic biodiversity in Indian Himalaya. Biodiversity and Conservation 16: 153-163.

Reynolds, R.T., J.M. Scott \& R.A. Nussbaum (1980). A variable circular-plot method for estimating bird numbers. Condor 82: 309313.

Riley, J. (2002). Population sizes and status of endemic and restricted range species on Sangihe Island, Indonesia. Bird Conservation International 12: 53-78.

Robin, V.V. \& R. Sukumar (2002). Status and habitat preference of White-bellied Shortwing Brachypteryx major in the Western Ghats (Kerala and Tamil Nadu), India. Bird Conservation International 12: $335-351$.

Stattersfield, A.J., M.J. Crosby, A.J. Long \& D.C. Wege (1998). Endemic Bird Areas of the World: Priorities for Biodiversity Conservation. BirdLife Conservation Series No. 7. BirdLife International, Cambridge, U.K.

Vijayan, L. \& V. Gokula (2006). Human impacts on forest bird communities in the Western Ghats, India. Acta Zoologica Sinica 52: 692-696.

Wijesinghe, M.R. \& M. L. deBrooke (2005). Impact of habitat disturbance on the distribution of endemic species of small mammals and birds in a tropical rain forest in Sri Lanka. Journal of Tropical Ecology 2: 1-8. 